\title{
The Voice of the 'Ulamâ': Fatwas and Religious Authority in Indonesia
}

\author{
Nico J.G Kaptein
}

\section{(2) OpenEdition \\ 1 Journals}

Édition électronique

URL : http://journals.openedition.org/assr/1038

DOI : 10.4000/assr.1038

ISSN : $1777-5825$

Éditeur

Éditions de l'EHESS

\section{Édition imprimée}

Date de publication : 1 janvier 2004

Pagination : 115-130

ISBN : 2-222-96741-4

ISSN : 0335-5985

\section{Référence électronique}

Nico J.G Kaptein, «The Voice of the 'Ulamâ': Fatwas and Religious Authority in Indonesia », Archives de sciences sociales des religions [En ligne], 125 I janvier - mars 2004, mis en ligne le 20 novembre 2012, consulté le 01 mai 2019. URL : http://journals.openedition.org/assr/1038 ; DOI : 10.4000/ assr. 1038 


\section{THE VOICE OF THE 'ULAMA'’ :FATWAS AND RELIGIOUS AUTHORITY IN INDONESIA}

\section{Introduction}

Religious authority is an extremely wide concept which may become manifest in an infinite variety of ways. It may be embodied in certain notions, in texts, in individual persons, in groups of persons, and in institutions in the widest sense of the word. For this reason, if a scholar wants to write an article about religious authority, it is essential to make a conceptual breakdown of the idea in order to write meaningfully on the subject. In the present contribution I would like to study the concept of religious authority in Indonesia (1) through the vehicle of the Islamic institution of ifta ', the delivering of a fatwa. In its classical form a fatwa consists of two parts: a question addressed to a scholar of Islam ('ulamâ' (2)) about a particular topic which has been addressed to him by one or more believers in order to obtain the scholar's opinion about this topic from the perspective of Islamic law. This part of the fatwa is called istifta', while the person who raises the issue is called the mustaftî (pl. mustaftûn). The second part of the fatwa is the actual answer given by the scholar, called the mufti, the "fatwa-giver". The language of the fatwa is very formal and formulaic. In the fatwa the mufti pronounces about issues which are of topical interest to the believer, by referring to the standard manuals of jurisprudence. These topics often deal with ritual issues, but in principle may deal with any conceivable topic, including social and political issues or problems arising from the application and use of modern technology. In the course of time, fatwas issued by important muftis have been collected and these collections can be regarded as manuals of applied legal science. In short, it can be said that fatwas constitute a meeting, and in many cases a compromise, between the ideals of the Holy Law, as expressed by the 'ulamâ', and the reality of daily life, as experienced by the believers. For a study of the working of religious authority the

(1) I use the term Indonesia not only to denote the present Republic of Indonesia, but also its predecessor the Netherlands East Indies.

(2) In the Indonesian language the word 'ulamâ' (which in Arabic is a plural) denotes both the plural and the singular (in Arabic 'alim). 
fatwa is useful, because the fatwa is an important instrument through which the 'ulamâ' express their authority, while conversely the istiftâ' shows that the believer has turned to the 'ulamâ' because they are regarded as being able to produce authoritative statements.

Throughout history the institution of iftâ' has undergone various changes. Once the preserve of individual muftis, later collective bodies also started to give fatwas. Moreover, new forms of the fatwa started to appear, and other fatwa-like statements issued by the 'ulamâ' began to be given, using both conventional as well as new media for their dissemination.

In the first part of this article I will observe a number of examples of fatwas and comparable expressions of religious authority in order to reveal some characteristic features of the institution of ifta $\hat{\prime}^{\prime}$, in particular with regard to the issue of religious authority in Indonesia. I have chosen these particular examples from the thousands of fatwas which I have at my disposal dating from the end of the nineteenth century up to today, for the reason that each one can be regarded as showing some elementary characteristics bearing on religious authority. I hasten to add that I have not made this choice because they reveal unique characteristics specific to these examples; these characteristics can also be encountered in other fatwas. Commenting upon the materials presented in this first part, in the second part of the article I will reflect on a number of aspects of religious authority as this is expressed in fatwas and fatwa-like documents. I will consecutively reflect upon the holders, the centres, the sources, the language, and the effectiveness of religious authority. The article will end with a few concluding remarks.

\section{I - Typology of fatwas}

\section{I.1 - Traditionalist fatwas}

The first example I would like to discuss comes from an important collection of fatwas, which is entitled Muhimmât al-nafâ'is fì bayân as'ilat al-hâdith ("The precious gems treating the explanation of questions about current topics"). This work consists of a large number of Arabic fatwas and their rendering into Malay, which were issued by the most prestigious Meccan muftis in the final quarter of the nineteenth century; most of these fatwas were issued by the great Shafi ite mufti of the Holy City, Ahmad Dahlân (d. 1886). These fatwas were given at the request of Muslims from the Malayo-Indonesian Archipelago.

Because these fatwas were issued in the period immediately prior to the introduction of new reformist ideas from the Middle East into the Netherlands East Indies, ideas which were inspired by Muhammad Abduh and others, the Muhimmât al-nafâ'is can be regarded as a reflection of the nature of traditionalist Islamic thinking of the period (3). The fatwas in this collection deal with all kinds of topics,

(3) This does not mean that after the rise of modernist thought in Indonesian Islam at the beginning of the twentieth century, when ijtihâd ('independent reasoning') became popular in Indonesia, traditionalist thinking disappeared. I shall return to this point later. 
including Islamic ritual, inheritance law, marriage law, food prescriptions, etiquette, local customs, and the relationship with the non-Muslim Dutch government. The example which I have selected deals with the question of the number of Friday mosques permitted in one single place. The Shari`a prescribes that, in principle, every community should have only one Friday mosque in which the collective Friday prayers should take place, but sometimes the need for a second one was felt, for example as the size of the cities expanded, or when rivalry arose within one congregation. In Indonesia various cases are known, for instance from Palembang (Rahiem, 1998, pp. 220-228), and although in the present fatwa the place of origin of the petitioner is not mentioned, this may well have been Palembang. The fatwa reads as follows:

"Question. What is your opinion - may your virtue endure - about one single place in which there are two Friday mosques located. The distance between these two is so wide that if the mu'adhdhin (4) of one of these two calls out the call to prayer, this does not reach anyone in the other mosque. Is it allowed that there are two Friday mosques or not? And, if you consider this permissible, must both of them then repeat the (Friday) afternoon prayer? Let us know your answer.

O God, guide us to what is right. The measure of the distance which permits the number of Friday mosques to be increased, is that someone who lives at the fringe of the place can reach the location of the mosque [only] with [such] great difficulty, that this is not tolerable according to the custom. This has been said by al-Jamâl al-Ramlî, and therefore in a case like this the enlarging of the number of mosques is allowed. But God knows best". The mufti of the Shafi ites al-Sayyid Ahmad Dahlân (Kaptein, 1997, pp. 111-112).

The first interesting feature of this fatwa to which I would like to draw attention is that, although it was meant for and requested by petitioners from Indonesia, it was given in Mecca. Of course, the significance of Mecca as the goal of the annual pilgrimage is undisputed in Islam, but in addition to this in the period in which this fatwa was issued, Mecca also formed the most important training centre for Indonesian 'ulamâ'. Mecca was home to a substantial group of Indonesian students and their teachers who resided there permanently, and who as a group formed the so-called Jâwah colony. In the words of the famous contemporary observer of Indonesian Islam C. Snouck Hurgronje (1857-1936), this Jâwah colony constituted 'the heart of the religious life of the East-Indian Archipelago' (Snouck Hurgronje, 1970, p. 291, cf. also p. 254). Although local muftis in Indonesia itself also issued fatwas, should no agreement be reached at home, the mustaftûn directed themselves to increasingly higher authorities, eventually ending up with the great Shafi ite mufti of Mecca, who was regarded by the petitioner(s) from Indonesia as the highest religious authority. In short, it could be said that this fatwa illustrates that at the end of the nineteenth century the most important centre of religious authority in Indonesian Islam was located in Mecca (5).

Another feature which is related to this has to do with the language used. As a matter of course the Shafi ite mufti of Mecca gave his fatwa in Arabic, and in order to ensure that its meaning would leave no room for misunderstanding, the fatwa was accompanied by a Malay rendering written in Arabic script, the so-called Jawi

(4) This is the mosque official who has the task to summon the believers to the mosque for the daily prayers.

(5) This also hold true for the seventeenth and eighteenth centuries, see AzRA, 1994. 
script. Apparently, the Malay rendering on its own was not considered enough for the Indonesian audience, and it was felt necessary to give the original Arabic as well to contribute to the authority of the fatwa.

A final important feature of the translated fatwa has to do with the legal methodology used. As was shown above, in order to answer the question the fatwa quotes an earlier classical handbook of Islamic jurisprudence as a source of authority, namely the one written by al-Ramlî. This is characteristic of the legal method used which is called taqlîd, i.e. the acceptance of the authority of earlier traditional scholars from one of the four canonical interpretations of the schools of law (madhhabs). In the case of the Netherlands East Indies, where the Shafi ite school of law was followed, the authorities most widely used were the Tuhfa ("The Gift"), by the sixteenth-century Meccan scholar Ibn Hajar al-Haytamî, and the Nihâya ("The Ultimate Goal"), written by another sixteenth-century scholar, al-Ramlî (Juynboll, 1930, p. 31). For the mufti, the principle of taqlid implies that he has to accept the opinions of his authoritative predecessors and that he was not allowed to arrive at any deviant opinions by independent reasoning (6). For the believers, this principle meant that they should accept the opinions expressed by these traditional authorities, as these were voiced by the mufti without questioning.

\section{I.2 - Modernist fatwas}

The next example which I have chosen, dates from the 1930s and was given by Ahmad Hassan (1887-1958). This scholar was a Tamil from Singapore who had emigrated to Indonesia in the $1920 \mathrm{~s}$, where initially his purpose was to start a textile business. In Bandung, Indonesia, he became involved in the recently established modernist organization Persatuan Islam (PERSIS, "The Islamic Union"). Hassan rapidly achieved authority in this organization, and soon he became its uncontested leader. The fatwa presented here was originally published in the Persis journal Pembela Islam ("The Defender of Islam"), which appeared between 1929 and 1935, and which contained a special section to answer questions from readers, entitled Soeal Djawab, "Questions and Answers". Although in the original form the fatwas from Pembela Islam mentioned the name of the mustaft $\hat{\imath}$, in the collection of the fatwas which I use here, the names of the petitioners have been removed, evidently because the fatwas were considered to be of importance not only to the original petitioners, but to the Muslim community as a whole. The fatwa deals with a typically Indonesian custom, namely the beating on a drum or the trunk of a tree which has been hollowed out, in order to gather the people for the prayer. The fatwa is in Malay and reads as follows:

"Question: Tree trunks, and drums are used in the local prayer houses to gather the people for the prayer. After this, they are summoned again with the call to prayer (adzan). What is your legal judgement about this?

Answer: Tree trunks and drums in order to gather the people for prayer were never been used by the Prophet or by his Companions. It is even known that some Companions put forward various ways of calling to gather the people for the prayer, but all of those were rejected by the Prophet.

(6) This understanding of taqlîd was not accepted by all scholars, JUYNBOLL, 1930, pp. 372-373. 
Because the Prophet had refused all methods of calling, apart form the adzan, it is also compulsory for us to reject all other manner of calling besides the adzan. Read the following account [from the Profetic Tradition Literature]: "When the Muslims had entered Madina, they were used to coming together and waiting for the [right time to start the] prayer, without anyone making the call for it. On a certain day they began to speak about this and some said: 'Let us use a drum like the drum of the Christians', while others said: 'Let us use a horn like the horns of the Jews'. Then 'Umar said: 'Why don't you order a man to make the call for prayer? For the Messenger of God has said: 'O Bilal, get up, and make the call for prayer' (a sound Hadith from al-Bukhârî and Muslim)".

After this Prophetic tradition yet another one is quoted in full (first in Arabic, followed by the Indonesian translation), making the same point. As the conclusion he draws on this issue Ahmad Hassan states:

"It is possible that some people will say that beating a tree trunk or a drum is more audible to the people who want to pray. Our answer to this is that in the villages where the drum or something else is not beaten, more people attend the prayer than in villages where they do" (Hassan, 1985, I, pp. 99-100).

Compared to the fatwa translated in the previous section of this paper, it is interesting to note that the petitioners had directed themselves to an authority in the country itself, and not to Mecca (7). Linked to this is the language in which the fatwa is given. In contrast to much earlier writings on Islam which were either in Arabic or in Kitab Malay, a form of Malay which teems with Arabic words and terms and which often can only be understood if one knows Arabic, the language Ahmad Hassan used is clear, non-technical Malay. Moreover, in contrast to these earlier writings which were in Arabic script (8), the script which he uses is the Latin script. In fact, Ahmad Hassan seems to have been very much concerned about the accessibility of his writings, since it is also known that he had his works translated into Sundanese, the local language of West Java (Minhaji, 2001, pp. 79-80).

The most interesting feature of this fatwa, however, is the method of reasoning employed by Ahmad Hassan. This reasoning is characteristic of the so-called "modernist" Muslim organizations which arose in the Netherlands East Indies at the beginning of the twentieth century under the influence of Middle Eastern scholars, like Muhammad 'Abduh and Rashid Rida. These movements affirmed the necessity of independent reasoning on the basis of the Qur'an and Hadith only, a method of legal reasoning called ijtihâd. Furthermore, they rejected the uncritical imitation of the authority of the standard interpretations of one of the established schools of law, the principle of taqlid mentioned earlier. Also in the same critical vein, these organizations also rejected many of the beliefs and practices of Muslims which had not been observed in pristine Islam and were, therefore, to be eradicated. Among the organizations which followed these modernist principles most strictly was Persis, led by Ahmad Hassan. In his writings Ahmad Hassan was very explicit about his legal methodology. He argued that scholars should practice ijtihâd on the basis of the Qur'an and the Hadith, which they should be able to read in the original Arabic. It was not necessary for the ordinary believers to know Arabic, but they should try to understand the reasons behind a certain opinion given by

(7) The same question was also asked to Ahmad Dahlân in Mecca (KAPTEIN, 1997, pp. 57-58).

(8) As a matter of course, Arabic texts were written in the Arabic script; texts in Kitab Malay were mostly also written in Arabic script, the already mentioned Jawi script. 
someone who made ijtihâd, a so-called mujtahid. This critical understanding was called ittibâ'. So, in the view of Ahmad Hassan there were only two ways to reach a certain opinion: ijtihâd or ittibâ', while taqlîd was strictly forbidden (Hassan, 1985, II, pp. 439-443; Minhaji, 2002, pp. 141-147). The fatwa translated here is a perfect illustration of the two basic reformist principles: it rejects local custom and its legal reasoning uses the method of ijtihâd, in this particular case not by referring to the Qur'an but to the Hadith as the source of authority.

\section{I.3 - Collective fatwas}

An important change which occurred from the beginning of the twentieth century, was that in addition to fatwas given by individual muftis, Muslim organizations began to give collective fatwas. I mention the three most important Indonesian Islamic organizations here as an example.

The biggest of these Muslim organizations is called the Nahdlatul Ulama (NU, "The Revival of the 'Ulamâ") with an estimated 35 million followers today. It was established in 1926 with the aim of defending the interests of traditionalist Islam. As an organization it has played and still plays an important role in political and socio-religious developments in Indonesian society. From its beginnings the NU has also issued fatwas. These fatwas are the result of a collective effort to reach a certain point of view in a process, which is designated by the Arabic term bahth al-masâ'il, "The Study of [Religious] Issues". Passing through lower regional levels of the organization, at its National Congress (Musyawarah Nasional), the NU comes with the final outcome to an issue in the form of a fatwa. In its way of reasoning the NU mainly follows the principle of taqlid, and in the motivation behind the answers reference is often made to traditional fiqh authorities which are quoted in the original Arabic without giving an Indonesian translation (9). It is interesting to note that as the intellectual heirs of the traditionalists' approach to legal interpretation the NU has recently conducted discussions about their legal methodology. In an effort to widen the fiqh discourse, since 1987 important discussions have taken place about the status and far too limited scope of the kitab kuning, the traditional sources of legal knowledge. The ideas which have been raised during these discussions have gained some ground in NU circles and in 1992 the National Conference held in Lampung reached an important decision which recognized the validity of a kind of collective ijtihâd, thus deviating from or, more appositely, transcending the purely traditionalist methodology (Bruinessen, 1994, pp. 220-234).

Another important organization in Indonesia which issues fatwas is the Muhammadiyah with an estimated number of 28 million members. In a similar manner to the Persatuan Islam referred to earlier, the Muhammadiyah was inspired by reformist ideas from the Middle East, like those of Muhammad 'Abduh. In 1912 it was founded as a religiously motivated social and educational organization. Since 1927 it has dealt with the issuing of fatwas in a special branch, which is today called the Majlis Tarjih dan Pengembangan Pemikiran Islam ("The Council of

(9) See the collected fatwas from the NU Congresses for 1926 - 1994, compiled by K.H.A. Aziz Masyhuri (MASYHURI, 1997). 
Tarjih and the Development of Islamic Thinking"), usually called the Majlis Tarjih. The term tarjîh clearly shows the legal methodology which is used within this council: legal reasoning is regarded as a way of "weighing" different opinions and choosing from among them the one which is regarded as most suitable to the circumstances and closest to the sources of law. True to its reformist principles, the main sources of law are the Qur'an and the Hadith, although at times traditional fiqh authorities may also be invoked. In cases which have not yet been dealt with by previous scholars, tarjîh is identical with ijtihâd. The Majlis Tarjih is organized hierarchically, with a central (national) board (based in Yogyakarta), regional boards, and district boards, and the decisions from a higher board are regarded as being more authoritative than those from a lower board. Many fatwas are delivered by the Majlis Tarjih at the request of Muslims from throughout the entire archipelago, and are disseminated through the bi-weekly magazine of the organization, Suara Muhammadiyah ("The Voice of the Muhammadiyah"). The fatwas may deal with all sorts of issues, often of a ritual kind. Whenever the fatwa quotes a Qur'anic verse or a Prophetic tradition to support its point of view, this is always done in Arabic, but it is always followed by the Indonesian translation (10). The fatwas are not reached after formal deliberations and a formal procedure of acceptance by the organization, and for this reason they are not regarded as binding; they represent a provisional point of view of the organization which might be changed should better or stronger arguments emerge up in the course of time (ANWAR unpublished). Another type of opinion given by the Majlis Tarjih is called a keputusan ("Decision") which will be dealt with in the next section.

In addition to these two independent Islamic organizations, I would like to mention the national government-sponsored organization the Majelis Ulama Indonesia, (MUI, "The Council of Indonesian Ulama"), which was founded in 1975 on the initiative of the then President Soeharto to function as a kind of interface between the government and the Muslim community at the national level. This initiative can be seen as an attempt by the government to involve the 'ulamâ' in its developmental policy in an institutionalized way. One of the domains in which the MUI is active is in the giving of fatwas, both to the government and to the Muslims in general. For this purpose the MUI has a special fatwa committee. The MUI is often in evidence in the media, and since its foundation has regularly delivered fatwas. Sometimes the government asks the MUI to lend religious legitimation to certain of its activities and, although the MUI is a government institution, it does not always automatically adopt the same opinion as the government. An example of this is a 1983 fatwa which forbade vasectomy, tubectomy and all forms of abortion, which really ran counter to the family-planning politics of the government (Mudzhar, 1993, pp. 46-54; 108-114; 122-123). The form of the MUI fatwas is reminiscent of the textual products of the governmental bureaucracy, referring to previous decisions of the MUI, government decisions, and summing up the considerations systematically, as in the promulgation of a state law; sometimes even the date from which a certain fatwa will be valid, is mentioned. As far as the legal methodology of the fatwas is concerned, this can best be characterized as eclectic, in the sense that any legal method can be found in examples of fatwas given by the

(10) Most fatwas of the Muhammadiyah have been published in Tim PP Muhammadiyah Majlis Tarjih, Tanya-Jawab Agama, 4 Vols. Yogyakarta, Penerbit Suara Muhammadiyah, 1991-1997. 
MUI (11). Apart from giving fatwas proper, the MUI also actively expresses its authority in other ways which shall be dealt with in the next section of this paper.

\section{I.4 Other forms of religious advice}

In addition to the fatwa proper, other types of fatwa-like texts which express the opinion of the 'ulamâ' can be come across. As an example of this, at this point I will translate a statement by the Majlis Ulama Indonesia. Unlike the two previous examples which I have translated, this one deals with politics, while the two previous ones bore more relation to the ritual sphere (12). The statement was released in the taushiyah ("Advice") section of Mimbar Ulama ("The Pulpit of the 'ulamâ"), the official mouthpiece of the MUI. This tausyiyah section includes various fatwa-like statements, like tazkirah ("Admonition"), pernyataan sikap ("Position Statement"), himbauan ("Appeal"), and sumbangan pemikiran ("Contribution to Thought"). In theory, these pieces of advice are not regarded as having the same authority as a fatwa, because a fatwa is surrounded by stricter procedures, like the conditions the mufti has to fulfil in order to guarantee the quality of the advice (Ikhwan, unpublished). Another difference is that there is no particular question mentioned, which is invariably the case with the fatwa, but like the fatwa, these pieces of advice are given on the occasion of a certain event, which seems to warrant a reaction from the 'ulamâ'. As such, these various forms of unsollicited advice are also an expression of religious authority.

The present example is a so-called amanat ("Instruction") and was issued in the turbulent days prior to the General Election of June 1999, when Indonesia was submerged in a deep economic and moral crisis. The advice reads as follows:

"ADVICE (taushiyah): INSTRUCTION (amanat) TO THE ISLAMIC COMMUNITY (umat islam) ON THE OCCASION OF THE GENERAL ELECTION ON 7 JUNE 1999

The Leadership Board of the MUI and the Leadership of the National Islamic Organizations express their feelings of gratitude towards God Almighty, because the Indonesian people is going through an important phase of the democratic process, namely the campaign for the General Election which will take place in a relative good, safe and unhindered way, although it should be admitted that there are still cases which deviate from and violate legal rules and regulations, as well as political norms and ethics.

The Leadership Board of the MUI and the leadership of some national Islamic organizations hold the opinion that voting in the General Election constitutes a social political contract and the transference of a mandate from the people to their representatives who are entrusted to carry out this mandate.

In connection with this, on the occasion of the day of the elections on 7 June, 1999, the MUI and the National Islamic Organizations, following the guidance of the word of God Almighty in Surat Âl 'Imrân (13) verse 28, which reads: "Let not the Believers (orang-orang mukmin) take the Unbelievers (orang-orang kafir) as their leaders (pemimpin)", issue the following instruction:

(11) See for the collected fatwas of the MUI, H.A. Nazri AdLANi et al., 1997

(12) I would like to stress here that this does not mean that fatwas are limited to the ritual and ceremonial sphere; they might just as well deal with the public sphere, see for instance KAPTEIN, 2000.

(13) This is the third chapter from the Qur'an. The verse is quoted only in the Indonesian rendering. 
1) The Indonesian people, in particular the Muslim community, should use their right to vote properly and responsibly according to their conscience by choosing that political party which is believed to strive for the aspirations and the interests of the Islamic community, the people, and the state.

2) The Islamic community should vote with sincerity (ikhlas) and with the intention of obeying God for one of the political parties which genuinely promotes candidates for the legislative assembly, who are adherents of the religion of Islam and who uphold high moral standards.

3) The Islamic community should be aware of the revival of the danger of communism, authoritarian and secular powers by means of the political parties which participate in the General Election and which as a matter of principle include hatred of Islam and the accomplishments of the Republic of Indonesia.

4) The Islamic community should submit itself permanently to God, and should multiply its prayers to God for the safe, democratic, fair, and honest (14) progress of the Election, so that the Indonesian people can escape from their various crises and achieve a new Indonesian society under the protection of the mercy of God Almighty.

Thus reads the Instruction to the Islamic community on the occasion of the 1999 Election. May God Almighty always grant His mercy generously and help to the [Islamic] community and the people of Indonesia as a whole".

Jakarta, 16 Shafar 1420 H/1 Juni 1999 M

THE LEADERSHIP BOARD OF THE MAJELIS ULAMA INDONESIA

General Chairman, (signed) Prof. KH. Ali Yafie

General Secretary, (signed) Drs. H.A. Nazri Adlani (15)

In the days after it was issued, this amanat was discussed on the front pages of the two Indonesian newspapers which I read, Republika and The Jakarta Post. Political analysts thought this instruction was directed against the Partai Demokrasi Indonesia Perjuangan (PDI-P, "The Indonesian Democratic Party for the Struggle") headed by Megawati Soekarnoputri. This party had several non-Muslims on its list, like the well-known economist Kwik Kian Gie, who has a Christian background. It was argued that by issuing this instruction the MUI had interfered in party politics, and for this reason it was heavily attacked. Some reactions argued that in addition to the religious affiliation of the candidates, other features should also be taken into account. Some, amongst them, Abdurrahman Wahid in his capacity of chairman of the Partai Kebangkitan Rakyat (PKB, "The party of the Resurrection of the People") and Amien Rais of the Partai Amanat Nasional (PAN, "The National Mandate Party"), claimed that this electoral advice would lead to a polarization between Muslims and Christians, which would weaken the reformation process. Others stressed that the Muslim majority should also become patently clear in the results of the election. One person who said so was Ahmad Syafi'i Ma'arif, the chairman of the Muhammadiyah, who stated that a non-Muslim dominance in parliament would turn out to be a time bomb. After he had been questioned on the matter, Ali Yafie declared that the MUI had not issued this instruction to cause hatred or to obstruct the PDI-P. His only goal in issuing this instruction was to give a religious dimension to the political process which seemed to be oriented towards worldly successes. To this he added that the religious aspirations of a Muslim were not shared by a non-Muslim. Finally, it is noteworthy that Ali Yafie indicated that

(14) The Indonesian reads luber dan jurdil.

(15) The text is found in Mimbar Ulama, no 250/XXI Rabi'ul awal 1420 H/June 1999 M, p. 27. 
this particular instruction represented a moral message which was stronger than a fatwa (Republika Online 2-6 Juni 1999; The Jakarta Post Online 2-6 June 1999).

This case is interesting because it shows that the opinion of the MUI was paid considerable attention and formed a hot item for almost a week; so, in this sense the voice of the 'ulamâ' was definitely heard. However, when we look at the outcome of the elections, it appears that this statement of religious authority was not effective at all: although this MUI instruction was addressed to the Muslim community at large, the PDI-P with 37.4 percent of the votes became the most powerful party in the country, while generally speaking it would be fair to say that the Muslim parties did not do well (Ikhwan, unpublished).

Also the Majlis Tarjih of the Muhammadiyah produces other documents in addition to fatwas. The 'fatwa-like' documents I refer to here are called keputusan ("Decisions"), which are reached during a National Tarjih Conference. Besides the regular members of the Majlis Tarjih, 'ulamâ', intellectuals (both male and female), and other knowledgeable members of the organization are involved. Once these decisions are officially promulgated by the Central Board of the Muhammadiyah, they are binding on the organization itself, as well as on its individual members. Because the decision has been reached after an institutionalized and formal process of decision making, it can only be abrogated after a similar procedure for nullification has been followed. One interesting example of a keputusan deals with a case leading to the conclusion that a female medical doctor could become the director of an hospital, in spite of the existence of Qur'anic verses and Prophetic traditions which might be understood to indicate the opposite (Anwar, unpublished).

The interesting thing about these two examples is that both represent new forms of expressions of religious authority. According to its chairman, this particular amanat issued by the MUI should be regarded as more authoritative than a fatwa, while within the Muhammadiyah the decision (keputusan) expresses more authority than the traditional fatwa. Another new phenomenon which has become apparent in both organizations is the involvement of women in the process of formulating an authoritative statement. As was mentioned above, also females participate in the Majlis Tarjih. Moreover, a female scholar, Prof. Zakiah Darajat, sits on the Central Board of the Majlis Ulama Indonesia (Subhan, 2002, p. 170).

\section{II - Foundations of religious authority in fatwas}

In this part of my article I would like to introduce some general reflections about the concept of religious authority in as far as this is expressed in fatwas and fatwa-like documents. For the sake of clarity, I put these remarks under separate headings, although they are in fact closely interrelated.

\section{II.1 - Holders of religious authority}

As we have seen above, traditionally religious authority resided in individual muftis. However, after the foundation of indigenous Islamic organizations from the beginning of the twentieth century, religious authority was also voiced collectively 
by special sections of independent Muslim organizations. As far as the involvement of the 'ulama' in the state apparatus is concerned, it may be said that the administrators, both in the colonial era and after independence, have always been aware of the potential political power of the 'ulamâ', and therefore have always sought ways to use the authority of the 'ulamâ' to legitimize state policy. This has resulted in various state-founded councils of 'ulamâ', and culminated in the establishment of the Majlis Ulama Indonesia in 1975 (Mudzhar, 1993, pp. 46-47). Although in the examples I have dealt with, I have followed a diachronical perspective, this does not mean that the older forms of fatwas have been replaced by the newer in a kind of natural evolution. This is certainly not the case and in present-day Indonesia all types of fatwas with which I have dealt still occur. For the concept of religious authority the implication is that this type of authority may be embodied in both individuals as well as in organizations. One interesting newer development is that apart from men, nowadays women also participate in embodying and expressing religious authority.

\section{II.2 - Centres of religious authority}

The first example makes it clear that the people of Indonesia directed themselves to Mecca in order to gain - what they regarded as the most authoritative religious advice on a particular issue, and implicitly that apparently the advice which they had obtained at home was regarded as inferior. Like C. Snouck Hurgronje, we thus might say that before the transmission of new reformist ideas from Egypt to Indonesia from the beginning of the twentieth century, Mecca was the most important centre of religious authority in Indonesian Islam. With the dissemination of the new legal methodology, called ijtihâd, a new centre of religious authority arose, Cairo. It is known that many Indonesians from the Malayo-Indonesian Archipelago addressed themselves to the Cairo-based reformist journal al-Manâr, which was published from 1898 till 1935 under the supervision of Muhammad 'Abduh and Rashid Rida when they wished to obtain a fatwa (Burhanudin, unpublished). However, Cairo did not replace Mecca as the most important centre from which to ask fatwas: in the eyes of the traditionalist Muslims, Mecca maintained this position, while for modernists Cairo assumed more importance (16). Today, as we have seen above, when asking fatwas many Muslims address themselves to muftis or organizations within Indonesia itself, and many issues are solved in this way. For these Muslims, the centre of religious authority is located within Indonesia itself. Our investigation has shown that, in Muslim organizations with their national, regional, and local boards, there is a hierarchy in religious authority: a statement from a lower-ranking board is considered less authoritative than one from a board closer to the centre.

All this does not mean that the Middle East no longer plays a role. Many collections with fatwas from Middle Eastern 'ulamâ', which were originally published in the Middle East, circulate in Indonesia in translation. Furthermore, at times Indonesians still request fatwas from the Middle East. A well-documented

(16) Of course, for the reformist Muslims Mecca continued to retain its importance as the goal of the pilgrimage. 
example of this are the fatwas given by several muftis from Saudi Arabia who can be regarded as representatives of the ultra-conservative Salafi type of Islam preached by the late state mufti of Saudi Arabia, ‘Abd al-`Azîz ibn Bâz (d. 1999). On 6 April, 2000, these fatwas legitimized the establishment of a paramilitary group, called Laskar Jihad that aimed to end the religious tensions between Muslims and Christians in the Moluccas, Eastern Indonesia, by the simple expedient of eradicating all Christians in the jihad (Hasan, unpublished). From time to time Indonesians also turn to the famous Al-Azhar University in Cairo for religious advice. Nonetheless, on the whole it may be said that the orientation towards the Middle East is definitively less than it used to be. All in all, in contrast to the end of the nineteenth century when there was one outstanding centre of religious authority, today this is no longer the case. Besides Mecca, new centres have come up, not only in the Middle East, but as I have shown above also in Indonesia itself.

\section{II.3 - Sources of religious authority}

In the first place, an important source of authority is the institution of iftâ', especially the person of the mufti himself. According to legal manuals a person should be properly qualified to be able to function as a mufti. Although the qualifications which have to be fulfilled to be recognized as a mufti may differ, in general it may be said that a mufti should be well versed in the sacred texts and legal precedents, as well as having an impeccable reputation as a person of high moral integrity (17). Again, the source of authority may also be located in collective bodies which are composed of qualified, respected persons; sometimes these bodies may also derive part of their authority from their being a part of the state bureaucracy. An additional factor which might give a certain opinion more authoritative value is located in the strict procedures which are followed in reaching a point of view. As we have seen above, in the Muhammadiyah a keputusan, which forms the end of long formal deliberations, is regarded as expressing more authority than a fatwa.

Another type of source of authority is religious texts. In traditionalist Islam, which in the domain of fatwas is primarily ruled by the principle of taqlid, these texts consist mainly of the classical authoritative legal handbooks. In modernist Islam, which in the domain of fatwas primarily follows the principle of ijtihâd, the main sources of authority are the Qur'an and the Hadith. On the whole, I think that in the present age with the enormous dissemination of opinions through printed works and electronic media, the 'ulamâ' are more concerned with the accessibility of certain Islamic points of view for the rank and file believer, who is increasingly better educated and therefore in a better position to understand the underlying religious motivation behind a certain point of view. For this reason, further research may show that nowadays there is more often direct reference to the Qur'an and the Prophetic tradition literature as sources of religious authority, while less attention is paid to technical elaborations from the classical legal literature of the schools of

(17) See for an analysis of four Hanafite texts relevant to South Asia, which comment on the qualifications of a mufti, MASUD, 1984. Normally, knowledge of the Arabic language is also mentioned. See, for an example from Indonesia from the Shafi ite madhhab, 'Uthman, 1313/1895, pp. 24-48. 
law. In this sense, there is some reason to speak perhaps of an erosion of traditional religious authority.

\section{II.4 - The language of religious authority}

Arabic as the language in which the Qur'an was revealed is, of course, the language of religious authority par excellence. Traditionally, the predominance of Arabic had to do with the prominent place attributed to Middle Eastern institutions in Indonesian Islam and, secondly, with the presence of a small, but influential group of Arabs in Indonesia. These Arabs originated from the Hadramaut in the southern part of the Arabian Peninsula and played an important role in the introduction of Islam into the Archipelago where they made a tremendous contribution to religious life in Indonesian society (Riddell, 2001). In their missionary efforts these Arabs often used their mother tongue, and this is an additional reason why Arabic was so important in Indonesian Islam. The first example given in this paper underlines the importance of Arabic until as late as the end of the nineteenth century, although of course Arabic by that time was not the only language in which fatwas were given. From the beginning of the twentieth century onwards we see that alongside Arabic, Malay also assumed a more important position as a language of religious authority. The first Malay fatwas from this period (18) still use the Arabic script, and thus through the script the text is still invested with something of the sacred language. Later this script was in its turn replaced by Latin script, as was the case with the fatwas of Ahmad Hassan. When texts are quoted in the fatwas to support a certain point of view, be it from the Qur'an, from the Hadith or from legal authorities, we see that sometimes these quotations (including Qur'anic verses) are given directly in Indonesian. In cases when these pieces of textual evidence are given in Arabic, they are almost always followed by an Indonesian rendering. In this way the position of Arabic as the religious language par excellence is underlined, but at the same time this enables the audience who is not conversant with the holy language, to understand the meaning of the texts. This is, of course, very different from earlier periods when believers were expected to follow the opinions of the muftis uncritically and the actual understanding of the issues concerned from a legal point of view was more a matter of religious specialists who knew Arabic.

\section{II.5 - Effectiveness of religious authority}

Whether or not the individual or institutional authority as expressed in fatwas is recognized depends on various circumstances. In dealing with the same issue, under different historical and socio-political conditions, muftis might give different, or even contradictory, fatwas (19). Moreover, the charisma of a particular individual may also play a role in the acceptance of the fatwa, and whether or not a particular petitioner is prepared to accept the authority of a certain mufti or institution.

(18) Among the earliest examples from Indonesia are those in the reformist journal al-Munir (published in Padang from 1911-1916).

(19) See for example, different fatwas on the colonial administration in the Netherlands East Indies KAPTEIN, 2000. 
What certainly plays a role in the effectiveness of fatwas today is their enormous dissemination through printed media, radio, television, and the Internet. In order to find out whether or not a particular fatwa was effective, the reception of each case should be studied separately. The example given above of the MUI instruction about the 1999 General Election, for instance, shows that this instruction was not effective at all. However, other examples may be set against this to show that particular fatwas were heeded by the believers. Finally, it seems probable that the issues dealt with play a role: there may well be reason to expect that these successful fatwas will most likely deal with issues which are perhaps less related to the political and social domains, and more to the ritual and ceremonial sphere (20).

\section{Concluding remarks}

In this article I have described some important developments in the Indonesian institution of fatwa-giving in the last hundred years; I have dealt in detail with two fatwas, one from the end of the nineteenth century and the other from the 1930s, and have discussed a so-called Instruction (amanat) from 1999. Each of these three documents can be regarded as showing elementary characteristics having a bearing on religious authority. Commenting upon the materials presented in this first part, in the second part of the article I have reflected on a number of topics which emerge from fatwas and fatwa-like documents and which are relevant to religious authority. These topics are the holders, the centres, the sources, the language, and the effectiveness of religious authority, and I have shown that the concept of religious authority is definitely not static, but very much subject to changes in the political, social, educational, and religious landscape in Indonesia.

In comparison with the end of the nineteenth century, it appears that nowadays religious authority is no longer the sole domain of the 'ulamâ', who as religious specialists par excellence had monopolized religious interpretation for a long time. As one of the results of mass education and growing literacy, we see that educated non-specialists enter religious debates, and thus participate in the shaping of a new religious authority. On the other hand, we see that many 'ulamâ' have become more concerned with the accessibility of religious discourse, for instance by expressing themselves in less technical language and in vernacular language, and thus from their part also contribute to the shaping of new forms of religious expression. Therefore, we may say that in addition to the traditional voice of the 'ulamâ', new voices have emerged, not only from the circles of the 'ulamâ' themselves, but also from outside these. What the consequences for the future development of religious authority will be God knows best.

Nico J.G. KAPTEIN

Leiden University

(20) In the ritual sphere might be included matters which have great social implications, like marriage and divorce. 


\section{BIBLIOGRAPHY}

ADLANI H.A. Nazri et al., ed., Himpunan fatwa Majelis Ulama Indonesia, Jakarta, MUI, 1997.

ANWAR Syamsul, "The Fatwa, Purification and Dynamization: A Study of Tarjîh in the Muhammadiyah ", Paper Presented at the workshop Fatwa and the Dissemination of Religious Authority in $20^{\text {th }}$ Century Indonesia, Leiden, 31 October 2002 [unpublished].

AZRA Azyumardi, Jaringan Ulama Timur Tengah dan Kepuauan Nusantara Abad XVII dan XVIII : Melacak Akar-akar Penbaruan Pemikiran Islam di Indonesia, Bandung, Mizan, 1994.

BRUINESSEN Martin van, NU: Tradisi, Relasi-relasi Kuasa, Pencarian Wacana Baru, Yogyakarta, LKIS, 1994.

BURHANUDIN Jajat, "Aspiring for Islamic Reform: the Voices of Malay-Indonesian Muslims in al-Manar », Paper Presented at the workshop Fatwa and the Dissemination of Religious Authority in $20^{\text {th }}$ Century Indonesia, Leiden, 31 October 2002 [unpublished].

HASAN Noorhaidi, «Transnational Islam within the Boundary of National Politics: Middle Eastern Fatwas on Jihad in the Moluccas ", Paper Presented at the workshop Fatwa and the Dissemination of Religious Authority in $20^{\text {th }}$ Century Indonesia, Leiden, 31 October 2002 [unpublished].

HASSAN Ahmad, Soal-Jawab Masalah Agama, Vols. 1 and 2, Bangil, Pustaka Tamaam, 1985.

IKHWAN Moch Nur, "'Ulamâ', State and Politics: The Council of Indonesian 'Ulamâ' in the Post-Soeharto Era ", Paper Presented at the workshop Fatwa and the Dissemination of Religious Authority in $20^{\text {th }}$ Century Indonesia, Leiden, 31 October 2002 [unpublished].

JUYNBOLL Th.W., Handleiding tot de Kennis van de Mohammedaansche Wet volgens de Leer der Sjâfi 'itische School, vierde onveranderde druk, Leiden, Brill, 1930.

KAPTEIN Nico, The Muhimmât al-nafâ'is: a Bilingual Meccan Fatwa Collection for Indonesian Muslims from the End of the Nineteenth Century, introduced and presented by Nico Kaptein, Jakarta, 1997 (= INIS Materials 32).

KAPTEIN Nico, "Acceptance, Approval and Aggression: Some fatwâs Concerning the Colonial Administration in the Dutch East Indies ", Al-Jami 'a (Yogyakarta), Vol. 38, nº. 2, 2000, pp. 297-309.

MASUD M. Khalid, «Âdâb al-Muftî: The Muslim Understanding of Values, Characteristics, and the Role of the Muftî», in Barbara Daly METCALF, ed, Moral Conduct and Authority: The Place of Adab in South Asian Islam, Berkeley, University of California Press, 1984, pp. 124-151.

MASYHURI K.H.A. Aziz, ed., Masalah Keagamaan Hasil Muktamar dan Munas Ulama Nahdlatul Ulama, Surabaya, Dinamika Press, 1997.

MINHAJI Akh., Ahmad Hassan and Legal Reform in Indonesia, Yogyakarta, Kurnia Kalam Semesta, 2001.

MUDZHAR Mohammad Atho, Fatwas of The Council of Indonesian Ulama: A Study of Islamic Legal Thought in Indonesia 1975-1988, Jakarta, INIS, 1993 (= INIS Materials 17).

MUI, «Taushiyah Amanat Umat Islam Menyongsong Pemilu 7 Juni 1999 », in Mimbar Ulama, $n^{\circ}$ 250/XXI, Rabi'ul Awal 1420 H/Juni 1999 M, p. 27.

NOER Deliar, The Modernist Muslim Movement in Indonesia, 1900-1942, London, Oxford University Press, 1973.

RAHIEM Husni, Sistem Otoritas dan Administrasi Islam: Studi tentang Pejabat Agama Masa Kesultanan dan Kolonial di Palembang, Jakarta, Logos, 1998.

RIDDELL Peter G., " Arab Migrants and Islamization in the Malay World during the Colonial Period », Indonesia and the Malay World, Vol. 29, $\mathrm{n}^{\circ}$ 84, 2001, pp. 113-128.

SNOUCK HURGRONJE C., Mekka in the Latter Part of the 19th Century; Daily Life, Customs and Learning. The Muslims of the East-Indian Archipelago (transl. by J.H. Monahan), Leiden, Brill, 1970 [Reprint of the 1931 English Translation of the Second Volume of the 1888-1889 German Original].

SUBHAN Arief, «Prof. Dr. Zakiah Daradjat: Pendidik dan Pemikir», in Jajat BURHANUDIN, ed., Ulama Perempuan di Indonesia, Jakarta, Gramedia, 2002, pp. 138-173.

Tim PP Muhammadiyah Majlis Tarjih, Tanya-Jawab Agama, 4 Vols. Yogyakarta, Penerbit Suara Muhammadiyah, 1991-1997.

'UTHMAN, Kitāb al-qawânîn al-shar'iyya li-ahl al-majâlis al-hukmiyya wa-l-iftâ'iyyah, Bogor, Maktabat `Irfân, 1313/1895. 
Abstract

In this article I deal with the concept of religious authority in Indonesia by means of studying a number of fatwas and comparable documents. Through the medium of the fatwas, the 'ulamâ' express their opinion from the point of view of Islamic Law about all kinds of topical issues submitted to them by believers, and for this reason a fatwa forms an important expression of religious authority. In the first part of the article I describe some important developments in the Indonesian institution of fatwa-giving in the last hundred years; in this part I deal in detail with two fatwas, one from the end of the nineteenth century and the other from the 1930s, and discuss a so-called Instruction (amanat) from 1999. Each of these three documents can be regarded as showing elementary characteristics pertinent to religious authority. Commenting upon the materials presented in this first part, in the second part of the article I reflect on a number of topics which emerge from fatwas and fatwa-like documents and which are relevant to religious authority. I deal consecutively with the holders, the centres, the sources, the language, and the effectiveness of religious authority. The article ends with a few concluding remarks.

\section{Résumé}

Dans cet article j'aborde le concept d'autorité religieuse en Indonésie à travers l'étude d'un certain nombre de fatwas et de documents similaires. Par le biais des fatwas, l'" Oulema » exprime son opinion, du point de vue de la loi islamique, à propos de toutes sortes de questions d'actualité qui lui sont soumises par les croyants, et c'est pour cette raison qu'une fatwa représente une expression importante de l'autorité religieuse. Dans la première partie de l'article je décris les changements importants qui se sont produits depuis un siècle en Indonésie dans le processus de prononciation de fatwas. J'y étudie en détail deux fatwas, l'une datant de la fin du XIXè siècle et l'autre des années 1930 et je discute aussi une Instruction (amanat) de 1999. Chacun de ces trois documents peut être considéré comme présentant les caractéristiques élémentaires de l'autorité religieuse. Dans la seconde partie de l'article, en commentant ces documents, j'aborde une série de questions soulevées par les fatwas, ou les documents du même ordre, relevant de l'autorité religieuse. En conclusion j'aborde la question des détenteurs, des centres, des sources, du langage et de l'efficacité de l'autorité religieuse.

\section{Resumen}

En este artículo abordo el concepto de autoridad religiosa en Indonesia a través del estudio de un cierto número de fatwas y de documentos similares. Por medio de las fatwas, el "Ulema" expresa su opinión, desde el punto de vista de la ley islámica, a propósito de todo tipo de cuestiones de actualidad que los creyentes le someten, y es por esta razón que una fatwa representa una expresión importante de la autoridad religiosa. En la primera parte del artículo, describo los cambios importantes que se han producido en Indonesia en el proceso de pronunciación de fatwas desde hace un siglo. Estudio en detalle dos fatwas, una que data de fin del siglo XIX, y la otra de los años 1930, y discuto también una Instrucción (amanat), de 1999. Cada uno de estos tres documentos pueden ser considerados como portadores de las características elementales de la autoridad religiosa. En la segunda parte del artículo, comentando estos documentos, abordo una serie de cuestiones retenidas por las fatwas, o los documentos del mismo tipo, que dan cuenta de la autoridad religiosa. En conclusión, abordo la cuestión de los detentores, de los centros, de las fuentes, del lenguaje y de la eficacias de la autoridad religiosa. 